\title{
Australian Surveys (1985-1992) for Insect Biological Control Agents of Hydrilla verticillata
}

by Joseph K. Balciunas

University of Florida

Department of Entomology and Nematology

Townsville Biological Control Laboratory

Townsville, Queensland 4811

D. W. Burrows

Australian Centre for Tropical Freshwater Research

Australian Biological Control Laboratory

Townsville, Queensland 4811

M. F. Purcell

CSIRO Division of Entomology

Long Pocket Laboratories

Indooroopilly, Queensland 4068

Final report

Approved for public release; distribution is unlimited 